\title{
Organizational-economic Mechanism of Formation and Realization of the Industrial Policy within the Framework of the CMEA and the EU: Experience and Prospects for Russia
}

\author{
Khachaturyan, Mikhail V \\ Candidate of economics, Associate professor of the Department for Theory of management and business \\ Technology of the PRUE, Plekhanov Russian University of Economics, 36 Stremyanny Lane, Moscow, 117997, Russian Federation \\ Email: mike-hach@mail.ru
}

Doi:10.5901/mjss.2016.v7n1p197

Abstract

The article analyzes the main stages of formation and functioning of organizational-economic mechanism of management of development and implementation of industrial policy in the framework of the Council for Mutual Economic assistance and the European Union. The article examines the main parameters of functioning of organizational-economic mechanism of management of development and implementation of industrial policy in the framework of the Council for Mutual Economic assistance. A special place has given to the analysis of the process of formation and functioning of organizational-economic mechanism of management of development and implementation of industrial policy within the European Union. Based on the author's analysis is put forward a point of view about the advantages and disadvantages of this mechanism. The article offers the author's interpretation of the composition of the organizational-economic mechanism of management of development and implementation of industrial policy of Russia. Based on the analysis of directions of application of the organizational-economic mechanism of management of development and implementation of industrial policy of Russia.

Keywords: organizational-economic mechanism, formation, realization, industrial policy, CMEA, EU, Russia, experience, prospects

\section{Introduction}

At present, it is clear that further progress in the economic system of Russia is impossible without systematic modernization of the structure and composition of the organizational-economic mechanism of management of development and implementation of industrial policy. Organizational-economic mechanism of formation and realization of the industrial policy in the broad sense can be defined as a purposeful influence on the formation and development of the sectoral structure of the economy through the formation and application of governance mechanisms at all levels of the economic system.

The peculiarity of the current state of scientific research on this problem is that most of them analyze either individual components of this process, or especially the impact of the mechanism on the processes of economic modernization of the country. It is obvious that the key problem of scientific understanding of the process under study is not the existence of the system of management of development and implementation of industrial policy, and its scale, form and intensity.

The main task of the organizational-economic mechanism of management of development and implementation of industrial policy is invited to consider the sustainable relationship between public and private corporations and research centers and clusters in order to develop measures to encourage industrial capacity of the economy. In the structure of the organizational-economic mechanism of management of development and implementation of industrial policy, according to the author, include:

- mechanisms of development, testing and subsequent commercialization of promising scientific research; system investment cooperation in the sphere of modernization of the industrial system of Russia on the basis of mechanisms of public-private partnership;

- infrastructure selection and monitoring of the implementation processes of the projects in the field of industry;

- a set of measures, methods and mechanisms for identifying threats, assessing and managing risks to economic security in the process of formation and implementation of industrial policy.

It is clear that the efficiency of the organizational-economic mechanism of management of development and implementation of industrial policy depends not only on the state of the productive forces of the country, the development 
of the relationship of the mechanisms of public-private partnerships with research centers, but also the involvement of the country in the processes of economic, industrial, scientific cooperation and integration.

In this regard, the relevant from the point of view of scientific thinking is the analysis of the experience of functioning of organizational-economic mechanism of management of development and implementation of industrial policy in the framework of the Council for Mutual Economic assistance and the European Union.

The present article aims to analyze the specific forms and methods of functioning of the organizational-economic mechanism of formation and implementation of industrial policy used in the framework of such a significant integration groupings as the European Union and the Council for Mutual Economic assistance. The article presents a retrospective analysis of the main instruments of harmonization of cooperation in the sphere of industrial policy of the countries participating in the EU and the CMEA.

\section{Literature Review: Organizational-economic Mechanism of Formation and Realization of the Industrial Policy within the Framework of the CMEA}

In modern economic literature, both Russian and foreign assess the effectiveness of the activities of the CMEA remains a matter of debate. But it is an undisputed fact that the CMEA was the basis of the integration of the socialist countries in the second half of the twentieth century. And under certain economic conditions in the region of the CMEA was a successful international structure, promoting the development of member countries after the Second world war. Obvious and the fact that the purpose of the activities of the CMEA, was in favour of the centrally planned economy. However, the philosophy of autarky, reliance on bilateral trade, the lack of reliable pricing mechanism, as well as the almost complete non-convertibility of national currencies is objective negative factors, inhibits the process of achieving the optimization of economic relations between the member States of the CMEA.

The CMEA was formally founded at a conference in Moscow in January 1949. By the founding members were Bulgaria, Czechoslovakia, Hungary, Poland, Romania and the Soviet Union. In February 1949 Albania is party. In 1950, the composition of the CMEA became the German Democratic Republic (GDR). In 1962, Mongolia, in 1972 - Cuba and in 1978, Vietnam. January 22, 1949, COMECON issued its first communiqué. This document during the first eight years until 1957 was considered merely a political statement, and during the next eleven years until 1968 founding document of the Commonwealth. The content of this document deserves a special mention: "In January this year during the economic conference held in Moscow, was attended by delegates from Bulgaria, Hungary, Poland, Romania, the USSR and Czechoslovakia. The conference noted the significant progress in the development of economic relations between countries and, primarily, a large increase of the trade turnover. As a result of the aforementioned economic relations and the implementation of economic cooperation between the countries of people's democracy and the Soviet Union, conditions were created to accelerate the reconstruction and development of their national economies. In addition, the Conference noted that the government of the United States of America, great Britain and some Western European States boycotted trade relations with the countries of people's democracy and the USSR, because these countries do not consider it appropriate to accept a dictatorship of the Marshall plan, which violates the sovereignty and interests of their national economies. In light of these circumstances, the meeting explored the question of the possibility for greater economic cooperation between the countries of people's democracy and the USSR. To establish this broader economic cooperation between the countries of people's democracy and the USSR, the conference considers it necessary to establish a Council for Mutual Economic assistance between these countries, based on equal representation and the task of economic exchange of experiences, technical assistance to each other and provide mutual assistance in respect of the supply of raw materials, foodstuffs, machines, equipment, etc. At the meeting it was resolved that the Council for Mutual Economic assistance organization will be open to other European countries sharing the principles of the Council for mutual assistance and wishing to participate in the expansion of economic cooperation with the above countries. The Council for Mutual Economic assistance will make decisions only with the consent of the concerned country. The Council will meet periodically in the capital city of each country, which at that time Chairman of the Board".

The author considers expedient will focus on the key points mentioned in the document.

First, it represents the Soviet principles of national sovereignty and was used as justification for refusal to participate in the Marshall Plan.

Secondly, proclaimed national self-sufficiency and the non-requirement of full economic integration.

In the author's opinion, a common misconception is that the CMEA was the source of supranational planning. The author considers reasonable Western economist E. Hewitt (1974), "... such Union centrally planned economies, in itself is decentralized and not centrally planned economy". Participation in any program of the CMEA was voluntary, and each member had the opportunity to influence the efficiency of the Council. 
The communiqué also was given a rating of trade embargoes by Western countries imposed on countries not participating in the Marshall Plan. At the time of establishment of the CMEA, about $50 \%$ of international trade contacts of the participating countries and China were frozen. (Kaser 1967). Therefore not only the process of post-war economic recovery, but the economic blockade, was the impetus for the creation of the CMEA. The primary objective for the member States, has been coordinating efforts and using trade as a tool of economic development of individual countries. To achieve this goal, member States to follow the model of development of the Soviet economy, with emphasis on heavy industry.

CMEA remained ineffective organization until 1953. And, since 1953, CMEA has developed rapidly until the collapse of the Soviet Union. However, full economic integration has not been achieved. In June 1962, adopted a new fundamental document "Basic principles of the international socialist division of labour".

In 1971 adopted a "Comprehensive program for the further deepening and improvement of cooperation and the further development of socialist economic integration" in the framework of the CMEA operated until 1990. It must be emphasized that these documents contain significant amounts of elements not only planned, but also the market system, but SAV and could not overcome the main obstacle, which was the state ownership of the means of production, created in international integration processes more difficulties than private property.

In the context of the study the analysis of the dynamics of integration processes in the framework of the CMEA shows the variability of demographic and economic statistics, indicating the unreliability or at best the accuracy of these data. But, nevertheless, they play a significant role in assessing how patterns of trade within the CMEA, and the activities of the organization as a whole. Important role in this work is played by the statistical data used in international research. Thus, in the work of J. van Brabant (1980), gives the following evaluation of the role of the USSR in the integration processes of the CMEA "about $90 \%$ of land and energy resources, $70 \%$ of the population, $65 \%$ of national income, $60 \%$ of industrial and $75 \%$ of agricultural production, and $40 \%$ of foreign trade". The ratio of the share of the Soviet Union and the European Economic Community as a trading partner of CMEA described in the following table

The share of the Soviet Union and the EEC countries in total exports of the CMEA countries in 1981 (\%).

\begin{tabular}{|l|c|c|}
\hline & The share of the EEC countries & the Share of the USSR \\
\hline Bulgaria & 11.5 & 48.3 \\
\hline Czechoslovakia & 19.6 & 37.6 \\
\hline GDR & 26.5 & 36.5 \\
\hline Poland & 29.5 & 34.2 \\
\hline Romania & 29.8 & 20.8 \\
\hline Hungary & 30.2 & 41.8 \\
\hline CMEA (6) & 29.5 & 35.9 \\
\hline
\end{tabular}

Source: Zwass A. 1989

From the table it can be concluded that the most dependent on the economy of the USSR was the Bulgarian economy, and relatively less dependent Romania. The table also allows to assert that there was no economic dictatorship in the CMEA.

No less interesting is the ratio of national product per capita of Eastern European countries in comparison with Romania as of 1938, the last pre-war year.

The ratio of national product per capita compared with Romania, according to 1938.

\begin{tabular}{|l|c|c|}
\hline & National product per capita in the US dollars & The attitude towards Romania in \% \\
\hline Romania & 38 & 100 \\
\hline Bulgaria & 43 & 113 \\
\hline Poland & 63 & 166 \\
\hline East Germany & 189 & 497 \\
\hline Czechoslovakia & 103 & 271 \\
\hline Hungary & 63 & 166 \\
\hline
\end{tabular}

Source: Zwass A. 1989

The author believes appropriate to substantiate the data of the table, data on the demographic situation in the CMEA countries in the postwar period, the most effective operation of the organization. 
Population (average annual rate: thousands of people)

\begin{tabular}{|l|c|c|c|c|}
\hline & 1950 & 1960 & 1970 & 1972 \\
\hline Bulgaria & 7.250 & 7,867 & 8.490 & 8,581 \\
\hline Hungary & 9.338 & 9.984 & 10.329 & 10.398 \\
\hline GDR & 18,388 & 17.241 & 17,058 & 17.043 \\
\hline Cuba & 5,368 & 6.826 & 8.553 & 8.732 \\
\hline Mongolia & 780 & 952 & 1.248 & 1.320 \\
\hline Poland & 24,824 & 29.5611 & 32.473 & 33.027 \\
\hline Romania & 16,3111 & 18.407 & 20,250 & 20,660 \\
\hline USSR & 180,075 & 214.334 & 242.757 & 250.000 \\
\hline Czechoslovakia & 12,389 & 13.654 & 14,334 & 14,478 \\
\hline
\end{tabular}

\section{Source: Galetskaia, R. 1974}

Based on these tables the obvious conclusion that the measure of National income per capita of the CMEA countries in the prewar period, compared with Romania was higher, and, consequently, their economies have developed more efficient. The dynamics of the demographic situation of the countries of the CMEA seems to be ambiguous, therefore, analyzing the results of the development of human capital can be more clear understanding of the primary industrial potential members of the CMEA and the effectiveness of the model of centrally planned economy, which finds confirmation in the following tables.

The volume of industrial production per capita in 1950 in comparison with the Soviet Union

\begin{tabular}{|l|c|}
\hline The Soviet Union & 100 \\
\hline Bulgaria & 43 \\
\hline Czechoslovakia & 143 \\
\hline GDR & 136 \\
\hline Poland & 70 \\
\hline Romania & 31 \\
\hline Hungary & 78 \\
\hline
\end{tabular}

Source: Zwass A. 1989

The share of industrial workers in full-time employment1950)

\begin{tabular}{|l|c|}
\hline & $\%$ \\
\hline Bulgaria & 13.0 \\
\hline Czechoslovakia & 30.0 \\
\hline East Germany & $41.2(1952)$ \\
\hline Poland & 17.8 \\
\hline Romania & $12.1(1951)$ \\
\hline Hungary & 19.7 \\
\hline USSR & 23.5 \\
\hline
\end{tabular}

Source: Zwass A. 1989

The contents of this table suggests that in the CMEA priority in economic planning was given to industrial development, while in the GDR and Czechoslovakia indicators such development were higher, therefore, the economy of these countries was better equipped to meet their needs. However, in subsequent periods as a result of application of the mechanism for coordination of planning based on the mechanism of specialization agreements, these figures had changed to the downside.

The share of CMEA in total exports in 1950 (\%)

\begin{tabular}{|l|c|}
\hline Total & 61.4 \\
\hline Bulgaria & 91.8 \\
\hline Czechoslovakia & 54.1 \\
\hline GDR & 68.0 \\
\hline Poland & 55.9 \\
\hline
\end{tabular}




\begin{tabular}{|l|c|}
\hline Romania & 89.2 \\
\hline Hungary & 66.4 \\
\hline USSR & 58.1 \\
\hline
\end{tabular}

\section{Source: Zwass A. 1989}

Based on the data table the obvious conclusion about the significance of the CMEA market for all its members, but especially the market value of the CMEA had for Bulgaria and Romania.

So, the statistical data allow to draw the following General conclusion, while in the CMEA was not used fully the mechanism of centrally planned economy, the economy of its member countries were centrally planned economies

The Council for Mutual Economic assistance was provided by the institutional framework in which the Soviet Union and its Eastern European partners undertook their economic relations. One of the goals of this organization was to increase economic integration between the member States. Important policy tool in achieving this goal was a system of special agreements. Therefore, in this study it is necessary to analyze the effectiveness of this instrument of economic integration within the CMEA.

Specialization and cooperation agreements were the main instruments of economic integration of the CMEA main industries in which these mechanisms were applied, were mechanical, and chemical production (Lyakina-Frolova, Kuvshinov, 1985). Agreements on specialization was the treaties, in accordance with which one of the participating countries had made a commitment to meet the needs of other members of the organization in a particular product, and other "not specializing" countries agree to limit or cease production of that product on its territory. Cooperation agreements included two companies from different countries in the production of a single product. One company usually supplied to another of certain components for the production. Specialization and cooperation agreements are distinguished by the fact that cooperation has formed a direct relationship between producers, while specialization involves the concentration of production of a particular product in one country. However, these two types of agreements are often intertwined. In the economic literature, as a rule, these terms are used in unity, and in the analysis between them there were no differences (Bogomolov, 1967, Kiss, 1971, Evstigneev, Shabunina, Usievich, 1983). It is therefore legitimate to distinguish between these two mechanisms of integration. Agreement of specialization are designed to encourage countries to develop comparative advantage in the production of certain goods, due to the construction of plants for the realization of economies of scale, the development of technical innovations in production and training, as well as the concentration of scientific research and development in the relevant field of specialization. These mechanisms were created to overcome the barriers of specialization arising from the system of trade in the CMEA. In view of the fact that mutual trade does not rest on the convertibility of the currencies of the participating countries, has formed a system quasipatterns exchange. Administrative arrangements pricing has led to the fact that the relative value of different traded goods were not reflected in the prices. Consequently, members of the CMEA, were forced to divide their trade balances on flows by commodity groups, with the aim of minimizing the losses from the exchange of goods with high demand for less expensive goods. This system has led to the expansion of the product range, but reduced the level of specialization. Thus, this system wore largely political rather than economic in nature.

The agreements provide for the types of products and the direction of trade between the parties, but they were not set out specific measures of trade. These agreements were concluded in the framework of the annual trade agreements. Articles on specialization and cooperation agreements were separate items in long term and annual trade agreements (Dezso 1971).

Obviously, the consolidation of provisions regarding the binding nature of such agreements for the companies included in the annual trade agreements, is an example of the use of administrative controls. In the CMEA agreement on specialization was usually for five years or in the order of 10 years, 15 years, due to practice, the use of methods of the five-year planning in member countries of the CMEA on the example of the USSR. This allowed the participating countries in the implementation of investment decisions taken on the basis of agreements of specialization and cooperation, to reimburse investment costs, but in compliance with the principle of voluntariness, as enshrined in the Charter of the CMEA, the importing country had the right out of agreements concluded, if they were contrary to its interests (Lyakina-Frolova, Kuvshinov, 1985).

In the practice of the CMEA, the agreement on specialization was divided into two categories:

1) intergovernmental agreements that were signed by the official representatives of the States, until the Supreme leadership of the country;

2) cross-sectoral or inter-Agency agreements, which, as a rule, was signed by the Ministers.

The intergovernmental agreement has formed the system of specialization and measures of co-operation, which 
was aimed at the design and manufacture of new products, representing a large economic or technological interest. For example, Long-term multilateral agreement on specialization and cooperation in production and mutual supplies of equipment for nuclear power plants, dated 28 June 1979, which was the intergovernmental (Lyakina-Frolova, Kuvshinov, 1985). Such programmes include a significant amount of investment of the participating countries and stimulated the creation of new industries.

Cross-sectoral or cross-sectoral agreements cover less significant areas. They included a system of exchange between one of the branches of two or more countries (Lyakina-Frolova, Kuvshinov, 1985). According Searscom agreement between Poland and Czechoslovakia, tractor accessories tractors exchanged for a similar tractor parts tractors or other types of tractors, but not for raw materials or other types of machinery (Lyakina-Frolova, Kuvshinov, 1985). Such agreements were less significant, because institutionally they were separate Ministers for foreign Affairs and external trade.

Agreements on specialization first appeared in the CMEA in the early 1950-ies. Two of them prisoners in 1956 were devoted to the field of ferrous metallurgy and production of bearings (Lyakina-Frolova, Kuvshinov, 1985). A significant fact is that the agreement of specialization have not been an important policy tool of the CMEA to the end of 1960-ies. In 1968, shortly after the opening of the Volga automobile plant, USSR bilateral agreements were signed with Hungary, Bulgaria and Poland, for which these countries have pledged to produce parts for cars VAZ. In 1969 one of the most important agreements were Multilateral Agreement to develop, manufacture and application of electronic equipment for data processing, the implementation of which led to the creation of integrated computer industry of the CMEA.

In 1971 signed a Comprehensive program for the further deepening and improvement of cooperation and development of socialist economic integration of member countries of the CMEA, which has led to increased use of the mechanism of agreements on specialization.

The number of agreements increased from a few dozen in 1970 to a few hundred in 1977, and exceeded a thousand in 1986.

The number of agreements on specialisation in COMECON, by country.

\begin{tabular}{l|c|c|c|c}
\hline & 1975 & 1976 & 1977 & 1986 \\
\hline Bilateral agreements by country & \multicolumn{4}{l}{} \\
\hline Bulgaria & 8 & 64 & 121 & 150 \\
\hline Czechoslovakia & 156 & 180 & 130 & 430 \\
\hline GDR & 305 & 305 & 362 & 243 \\
\hline Hungary & 114 & 161 & 162 & 194 \\
\hline Poland & 156 & 160 & 220 & 267 \\
\hline Romania & 39 & 63 & 106 & 124 \\
\hline Romania & 76 & 105 & 123 & 330 \\
\hline The total number of agreements & 419 & 519 & 637 & 888 \\
\hline Multilateral Agreements & 57 & 89 & 98 & 331 \\
Total & 476 & 608 & 735 & 1211 \\
\hline
\end{tabular}

\section{Source: Zwass A. 1989}

The volume of trade in goods, subject to agreements on specialization has increased from less than $1 \%$ of the total trade of the CMEA in 1970 to more than 20\% by 1976 (Rybalkin, 1978).

The intergovernmental Commission on economic, technical and scientific cooperation to play a major role in the development and implementation of agreements. These bilateral Commission existed between each pair of countries of the CMEA. It must be emphasized that in the organizational system of the CMEA, as in the system of European Community in parallel, but independently from each other are formed supranational governance bodies. The management bodies of the CMEA and the European Commission working on a permanent basis, has played an important role in the development agreements. The standing committees of the CMEA, and similar Offices of the European Community, were structured by industry, their task was to develop specific recommendations for specialization, and the Commissariats, the EU has developed and produced under modern conditions the General direction of economic and financial policies of the Community

In 1977 the USSR participated in 90\% of all multilateral agreements, almost as much as any other country of the CMEA, but less than the number of bilateral agreements concluded between more industrialized countries of the CMEA. The figures indicate that the Soviet Union was not the main driving force of most of the bilateral agreements on 
specialization. Small countries probably used bilateral agreements on specialization on inter-sectoral level is more active than the Soviet Union. A possible explanation for the popularity of bilateral agreements between these countries is that because of their limited domestic markets, they may have fewer opportunities for economies of scale. In order to eliminate inefficient production lines, they initiated several agreements. These cross-sectoral bilateral agreements enabled the participating countries to stop the production of small series of sophisticated equipment, which for these countries was ineffective.

If the specialization of the agreement has led to increased economic integration, their introduction would lead to changes in the system of distribution of goods. The share of production was sold in partner countries, as a percentage of total consumption imported from these countries, therefore, the volume of trade increased after the conclusion of the agreement.

Thus, the increase in the share of production exported, consumption, imports and partner countries, which is not an objective proof that the agreement on specialization has a positive impact on the strengthening of economic integration. The author feels justified to argue that integration on the basis of export shares of production and imports share of consumption was the objective tendency. After the signing of the agreement on specialization, the trend was to be developed, which indicated the effectiveness of this integration tool.

Since the countries of the CMEA had transactions of trade flows to exchange currency, the value of which had little relation to the national currency, to determine the exact amount of implicit subsidies is not possible. Also not legitimate to claim that the agreement on specialization has made a major contribution to the economic integration within the CMEA. The author came to the conclusion that the agreement on specialization has not led to the achievement of strategic objectives in the development of socialist integration. include:

Thus, several interrelated variables contributed to the inability to SAV to implement the strategic goals. These

- the elements of the structure of the group, primarily the voluntary participation of members of the CMEA in political and economic agreements;

- the establishment and maintenance of bilateral trade patterns;

- the non-convertibility of currencies;

- $\quad$ preservation of the centrally planned socialist economic model;

- maintaining a system of pricing that does not reflect real production costs.

In the second half of 1980-ies, when the system of the CMEA began the process of development towards the strengthening of multilateralism and the formation of a market economy, organizational practice reduced the effectiveness of these initiatives to zero. Ultimately, the tradition of member States to act in their own interests to the detriment of the organization of the CMEA as a whole resulted in the elimination of the Union.

Clearly, the model of organizational-economic mechanism of management of development and implementation of industrial policy in the framework of the CMEA was based on the priority of bilateralism over multilateralism and voluntary participation. The author considers it necessary to emphasize that, despite the apparent complexity of development, the system of the CMEA at a certain stage was competitive and in some issues of economic development, for example, the introduction of a common currency unit, ahead of the Western European Union. An important aspect played a significant role in the collapse of the CMEA, according to the author, is that this system was based on Central planning, which excluded the impact of fundamental economic laws of supply and demand. Significant for the CMEA was the impact of the pricing system is based on fixed prices of the world market of a particular product, purified from all vibrations. Ultimately, the transition of the USSR in 1990 to settlements with CMEA partners on real world prices led to the collapse of the system.

The purpose of this analysis of the process of formation and functioning of organizational-economic mechanism of formation and implementation of industrial policy in the CMEA is the need for a scientific analysis the possibility of using accumulated over the years, the organization of theoretical and practical experience in modern integration processes in the form of creating the Eurasian Economic Union. It is obvious that a direct adoption of the described techniques and methods not possible in view of the considerable differences of political and socio-economic conditions. However, the study of this experience, in the author's opinion, will allow to form a theoretical basis, of the processes and prevent the weaknesses and failures that led to the collapse of the CMEA.

\section{Results of Research: The Nature and Characteristics of Organizational-economic Mechanism of Management of Development and Implementation of Industrial Policy within the European Union}

In may 1948 Hague Congress was the beginning of the post-war process of European integration (Schuman, 1951). This 
process was based on the long history of European unity. The movement included several organizations some of which were domestic, the other international, which unites a large number of people in more than twenty countries (Lipgens, 1982). The idea of European unity in the post-war period was extended and had broad support. This Congress was an important milestone in the process of creation and development of the European Union, but at the same time have demonstrated differences among its participants. Was made a General agreement providing for the formation of the International Committee of Movements for European Unity, the structures that organized the Congress, to head the organization called the European Movement.

The next step in the process of economic integration was the creation of three major international organizations the European Coal Organization, the European Central Inland Transport Organization, and the emergency Economic Committee for Europe better known as the Administration of the Reconstruction and rehabilitation of the United Nations, which ceased to exist in 1949. Economic Commission for Europe of the UN included the rest of the emergency organization may 1947.

The final decision of the Hague Congress contained an obligation on the establishment of economic and monetary Union as the essential elements of the European Union. In fact. Western European governments have sought to restore the functioning of their own economic systems, not European economic integrity. In an unstable geopolitical, economic, and monetary environment, the government tried to maximize the preferences of national economies through the creation of many tariff and non-tariff barriers. Which led to the formation of customs unions. Belgium and Luxembourg formed an economic Union in 1921, which in 1944 join the Netherlands, which resulted in the customs Union of the Benelux countries. It was finalized in 1948, but the problems of the balance of payments in the Netherlands and partners are constantly improving non-tariff trade barriers hampered the prospects of deeper economic integration. In addition, the customs Union of the Benelux countries was not conceived as a first step towards greater unification of Europe, and as a protective mechanism against possible post-war economic recession and protectionist measures of large States. France initially showed interest only to the creation of a customs Union with Italy, and the establishment of a customs Union with other European countries was dictated not by a desire to access the European market, and to limit the speed of recovery of the German economy. Partially the order of creation of the Franco-Italian customs Union was agreed in March 1949. However, earlier the French idea to expand the customs Union of Benelux has found more support in Belgium and especially the Netherlands, which had close economic relations with pre-war Germany, their desire to participate in this Association was, in turn, dictated by the desire to speed up the process of recovery of the German economy. But France then offered a broader European customs Union, however, this project did not provide for the participation of Germany (Asbeek Brusse, 1997).

Thus, from the foregoing we can conclude that economic integration in those years was an idea whose time has not yet come. Organization for European Economic Cooperation was a prototype for the future process of European unification. But the UK opposed the delegation of the national economic functions of the Organization for European Economic Cooperation, as well as against the partial delegation of the national political functions of the Council of Europe advocating the preservation of national sovereignty.

The Marshall plan, the OEEC, and payments Union formed a cycle of economic growth in Western Europe, by encouraging countries to reduce tariff and non-tariff barriers, stimulating the growth of international trade. At the same time, participation in the General agreement on tariffs and trade (GATT) led Western European countries on the path to further global trade liberalization. The phasing out of trade protection has facilitated the emergence in the late 1950s, the European Economic Community.

J. Monnet, a leading statesman of France, proposed a modernization plan, which suggested the prospect of reaching the recovery of the French economy (Duchene, 1994). The Marshall plan called for the restoration of the German economy as an integral part of the recovery in the European economy, the Monnet Plan called for the restoration of the French economy at the expense of German economic weakness. This was especially true for coal and steel sectors, the foundations of industrial power in the mid-twentieth century in Europe. Historically, the lack in France of coking coal, which Germany had in abundance, especially in the Ruhr area in the West of the country, has been hobbled French steel production. Monnet based his plan for the modernization of the French steel industry assuming that Germany will remain in a situation of economic stagnation, while France will have unlimited access to Ruhr coal and will be able to exploit the post-war markets previously filled by German manufacturers. According to the $F$. Duchesne, biographer Monnet, France will develop its steel industry "on a diet Ruhr coke while she largely does not replace German steel" (Duchene, 1994). The Ruhr was in France as a symbol of militarism and the rise of Nazism. Management of the Ruhr was for France special economic and strategic interest. However, the governments of France and Germany was significant pressure from the US insisted on solving the problems of the Ruhr and the establishment of full-fledged economic relations between France and Germany. Such a solution was found and embodied in a document, which called 
the Schumann Declaration, on behalf of the Minister of foreign Affairs in the government of Charles de Gaulle by R. Schumann.

On the conclusion of the Schuman Declaration was declared on 9 may 1950. Schumann suggested and certain solution to the problem of the Ruhr, the creation of a supranational coal and steel organizations, and the General solution of the German question. The main objective was to ensure "the modernization of production and improving its quality; the supply of coal and steel on equal terms in French and German markets... and goods from other member States; and the adjustment and improvement of living standards and working conditions in these industries." (Schuman, 1999).

It can be concluded that the Schuman Declaration was a major turning point in Franco-German relations in modern European history. However, the owners of the coal and steel companies did not support this document, considering that the government has used the Declaration as a mechanism of redistribution of property. France and prospective partners Germany faced a similar set of internal circumstances. The implementation of the Schuman Plan in the form of the European Union of Coal and Steel, therefore, was ambiguous. The European Economic Community, to create anticipated in the form of a Common market, was the fifth initiative for the community of Western European countries in the 1950-ies. It was accompanied by the proposal to establish the European Atomic energy Community (Euratom) and followed the rejection of the European Defence Community, and was connected with attempts to create a European Political Community.

The above allows concluding that the European Union of Coal and Steel has not provided its founders expected the pace of economic growth in Western Europe. Tariff and quantitative restrictions were indeed reduced in the coal and steel sectors, but to identify and eliminate non-tariff barriers was more difficult. The market remained fragmented, competitiveness has not increased, the performance is not increased, and the cartels and monopolies regained their potential.

The creation of the Customs Union, common commercial policy, common agricultural policy were the major policy innovations in the first decade of the EC. Common agricultural policy was also the most famous innovation, thanks to the media coverage of the riots by farmers. By the end of the 1960s, the implementation of the Common agricultural policy has led to overproduction and environmental degradation of land, significant profit growth of large producers at the expense of small, and was not able to keep many small farmers on the land. The first signs of overproduction of agricultural products - butter and milk - appeared in 1968, which led to sharp criticism of the Common agricultural policy. The purpose of criticism were not the actions of the governments of member States and the Commission, constitutes the entire Community.

The Commission wore inconsistent, ambiguous influence on the integration processes and regional development. An example is Italy's economy, the only member state of the EU in the 1960s, in which there were serious regional problems, the South of Italy was much poorer than the North. Italy and the Commission, therefore, wanted that the EC had established an effective regional policy, including the fundamental regulation of the agricultural budget, part of the Common agricultural policy, dedicated to infrastructure development. The Commission organized a permanent conference on regional disparities in 1961 and established a General Directorate for regional policy in 1967. However, other member States were opposed to the spread of Community competence in the area, in their opinion, is not explicitly specified in the Rome Agreement.

The formal end of the transition period in the process of formation of the Common market was determined by the switching of the EU funding on the system of "own resources". There were two sources for these resources: tariffs on imports of industrial goods and taxes on the import of agricultural products, the rates determined by the General policy of the EC common commercial policy and the common agricultural policy, respectively. Because these resources were not sufficient to cover all expenses of the EC, member States should have in addition to pay a portion of their revenues from value-added taxes. The Commission's proposals on the formation of "own resources" in 1965 caused the crisis of the EU Commission, the so-called "empty chair Crisis" the entrance of which the position of the Commission as the governing body of the EU were severely compromised. In December 1969 the Council agreed to a phased introduction of own resources, including the national contribution up to $1 \%$ of the value added tax, in the period from January 1971 to January 1975, when the system will begin to function fully.

In 1973 the Council approved the program of harmonization and Programme of action in the industrial policy. They contained a set of legislative measures with a deadline for adoption of many of them no later than December 1977. But progress was slow. The Board took only eleven directives in 1973, thirteen in 1974, twelve in 1975. By the mid-1970s, numerous directives of the project is stuck in the mechanism of decision EC.

The lack of unanimity gave an opportunity for governments to prevent the Council directed the measures of harmonization. The extension has further complicated the process, because "the political relations to harmonization in Denmark and the UK were... different from polite skepticism to stridently hostile". National governments and the public 
condemned the Commission for its commitment to the implementation of the idea of homogeneity. The Commission recognized that "technical barriers and quantitative restrictions... and tight deadlines", but argued that the constant and rapid increase of non-tariff barriers in mutual trade was seriously weakened the potential of the Common market and destroyed public confidence in the Community.

Analyzed under this item, the sources and research materials allow to assert that the process of formation of organizational-economic mechanism of formation and implementation of industrial policy within the European Union, was accompanied by considerable difficulties due primarily to the large disparities in the level of economic potential of the participating countries. In the conditions of economic instability the need to address these imbalances become increasingly apparent, however, the formation of strategies of their elimination will require, in the opinion of the author no less effort from political, economic and scientific circles of Europe, than the whole process of forming the current European Union model. This process will also require the scientific and practical understanding of the processes that occurred and are occurring within the formation and implementation of the EU industrial policy and the shortcomings that reduced and reduce the efficiency of the process. According to the author, this Chapter focuses on the analysis of scientific sources can be used by researchers of economic integration within the EU as a base for further research.

The main methods used in this research are General scientific methods (scientific abstraction, deduction and induction), which made it possible to study the main stages of formation and functioning of organizational-economic mechanism of formation and implementation of industrial policy in the framework of the CMEA and the EU. These methods were used to study scientific works, devoted to the activities of the CMEA and the EU at different stages of their functioning, as well as to analyze the statistical data concerning the peculiarities of formation and implementation of industrial policy in the CMEA as an auxiliary at this stage of research were also specially-scientific methods (economic and statistical, econometric). Use of data scientific methods allowed a detailed analysis of the peculiarities of functioning of organizational-economic mechanism of formation and implementation of industrial policy in the framework of the CMEA and the EU. The application of the above methods have expanded the scientific significance of the article and has allowed to formulate the conclusions that can be used by scientists engaged in the issues of economic integration, the formation and implementation of the framework of industrial policy.

\section{Conclusion}

Based on the foregoing, we can conclude that the efficiency of functioning of organizational-economic mechanism of management of development and implementation of economic policy in General and industrial policy in particular within the European Union throughout the history of its existence has been fraught with many difficulties economic and political. The problem significance of the gap in levels of economic and industrial potential of the countries participating in the EU today. It is obvious that Russia is in the process of modernization of the organizational-economic mechanism of management, necessary to consider these aspects of learning from the European experience of modernization of the complex management system.

\section{References}

'A comprehensive program for the further deepening and improvement and development of socialist economic integration of member countries of the CMEA'. Moscow: Politizdat, 1972: 5

Asbeek Brusse W., (1997), 'Tariffs, Trade and European Integration 1947 - 1957: From Study Group to Common Market'. New York, St. Martin's Press: 52-63

Bogomolov, O.T. (1967), 'Theory and methodology of the international socialist division of labour'

Dezso H., (1971), 'The Results, Directions and Problems of Industrial Cooperation and Specialization'. Vi1aggazdang 17 September::143

Duchene F., (1994), 'Jean Monnet: The First Statesman of Interdependence'. New York, Norton: 147-156.

Evstigneev N. R., Shabunina, V. I., Usievich M. A., (1983), 'Development of economic mechanisms in the countries of the CMEA'. Moscow, Economics.

Galetskaia, R. (1974), 'The Demographic Situation in COMECON Member Nations'. Voprosy ekonomiki, 1974: 80-101.

Hewett, E. A. (1974), 'Foreign Trade Prices in the Council for Mutual Economic Assistance'. New York: Cambridge University Press: 1

Kaser, M. (1967), 'COMECON: Integration Problems of the Planned Economies'. London. Oxford University Press: 15

Kiss, T. (1971), 'Problems of socialist integration of the CMEA countries'

Lipgens W. A., (1982), 'History of European Integration Vol. 1: 1945 - 1947: The Formation of European Unity Movement'. Oxford, Clarendon Press: 89

Lyakina-Frolova, Y., Kuvshinov, V. (1985), 'Legal Aspects of Direct Ties'. Foreign Trade, November. Moscow, The Ministry of foreign trade of the USSR:. $6-43$ 
Rybalkin, V. E. (1978), 'International CMEA market. Development prospects in the context of economic integration'. Moscow, Thought: 60.

Schuman F. L., (1951), 'The Council of Europe'. The American Political Science Review 45, no. 3 (September): 726

Schuman R., (1999), 'Declaration of 9 May 1950'. London, Printer: 74

van Brabant, J. M. (1980), 'Socialist Economic Integration: Aspects of Contemporary Economic Problems in Eastern Europe'. New York, Cambridge University Press: 3

Zwass, A. (1989), 'The Council for Mutual Economic Assistance: The Thorny Path from Political to Economic Integration'. Armonk, New York, M.E. Sharpe, Inc., 1989. 